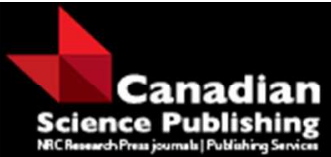

Canadian Journal of Forest Research Revue canadienne de recherche forestière

\title{
Long-term decline of sugar maple following forest harvest, Hubbard Brook Experimental Forest, New Hampshire
}

\begin{tabular}{|r|l|}
\hline Journal: & Canadian Journal of Forest Research \\
\hline Manuscript ID & cjfr-2017-0233.R2 \\
\hline Manuscript Type: & Article \\
\hline Date Submitted by the Author: & 21 -Oct-2017 \\
\hline Complete List of Authors: & $\begin{array}{l}\text { Cleavitt, Natalie; Cornell University } \\
\text { Battles, John; Department of Environmental Science, } \\
\text { Johnson, Chris; Syracuse University } \\
\text { Fahey, Timothy; Cornell University, Natural Resources }\end{array}$ \\
\hline Keyword: & $\begin{array}{l}\text { forest recovery, northern hardwood forest, priority effects, community } \\
\text { assembly, management implications }\end{array}$ \\
\hline $\begin{array}{r}\text { Is the invited manuscript for } \\
\text { consideration in a Special } \\
\text { Issue? : }\end{array}$ & N/A \\
\hline
\end{tabular}


CJFR-2017-0233

2 Long-term decline of sugar maple following forest harvest, Hubbard Brook

3 Experimental Forest, New Hampshire

4

5 Natalie L. Cleavitt; Dept. of Natural Resources, Fernow Hall, Cornell University, Ithaca, NY

$6 \quad 14853$

7 e-mail: nlc4@cornell.edu

8

9 John J. Battles, ESPM; Mulford Hall, University of California, Berkeley, CA 94720

10 e-mail: jbattles@,berkeley.edu

11

12 Chris E. Johnson; Dept. of Civil and Environmental Engineering, 151 Link Hall, Syracuse

13 University, Syracuse, NY 13244

14 e-mail: cejohns@syr.edu

15

16 Timothy J. Fahey; Dept. of Natural Resources, Fernow Hall, Cornell University, Ithaca, NY

$17 \quad 14853$

18 e-mail: tjf5@cornell.edu

19

20

21 Corresponding author: Natalie L. Cleavitt, 55 Perch Pond Road, Holderness, NH 03245;

22

603-960-2519; nlc4@cornell.edu 


\section{Abstract.}

Forest harvesting can impact site quality by removing essential nutrients, exacerbating

25 effects of historic base cation losses associated with acid deposition. We studied the 30-year

26 trajectory of forest recovery from clearcutting (whole-tree harvest (WTH)) in a forest originally

27 dominated by sugar maple (Acer saccharum). At both the watershed-scale (21.9 ha) and

28 “detailed" plot-scale $\left(1 \mathrm{~m}^{2}\right)$, a dramatic decline of sugar maple was observed, along with maintenance of American beech (Fagus grandifolia), and an increase in birch, mainly yellow birch (Betula allegheniensis). Many of the "detailed" plots where sugar maple failed to recruit

31 became unoccupied rather than being "won" by another species. The decline of sugar maple

32 was most severe in the upper elevation zones of the watershed, where low base status (especially

$33 \mathrm{Ca}$ ) of the soils was a likely driver. The results support previous studies indicating that

34 regeneration by sugar maple is severely compromised on base cation depleted soils. Lower

35 survival of seedlings for sugar maple emphasized the importance of maintaining advance

36 regeneration to favor desired species such as sugar maple. Foresters should consider that sites

37 with low base saturation and exchangeable $\mathrm{Ca}$ are likely to exhibit regeneration failure for sugar

38 maple in the long-term, even those with initial dominance by this species.

Key words: forest recovery, northern hardwood forest, priority effects, community assembly, 
42

\section{Introduction}

Concerns about the possible effects of repeated forest harvest on soil fertility were expressed long ago by Rennie (1957), who argued that calcium (Ca) removal by logging on basepoor silicaceous substrates could threaten Ca supply to recovering vegetation. These concerns were heightened when whole-tree harvesting (versus conventional stem-only harvesting) became a more common practice in the 1970s (Weetman and Webber 1972). Moreover, evidence of high base cation losses by leaching following forest cutting (Bormann et al. 1969) as well as chronically increased leaching resulting from acid deposition (Likens et al. 1972) raised further concerns about soil nutrient depletion. Early research summaries (Mann et al. 1988, Federer et al. 1989) concluded that despite some inadequacies of available information there was a strong basis for concluding that a Ca deficit owing to forest harvest plus acid rain effects might not be compensated by natural processes of mineral weathering, atmospheric deposition and detrital recycling on many base-poor soils.

In the northern hardwood forests of eastern North America maintenance of sugar maple (Acer saccharum Marsh.; ACSA) after forest harvest is a particular concern. Sugar maple supports the economically important maple syrup industry, provides particularly high quality lumber, as well as spectacular fall foliage, which is the heart of the autumn tourist trade in the northeastern United States (Caputo et al. 2016). Sugar maple re-establishment and survival are expected to be particularly problematic with respect to soil $\mathrm{Ca}$ depletion because of its high $\mathrm{Ca}$ requirement and known sensitivity to soil acidification (Long et al. 1997, Moore et al. 2000, Schaberg et al. 2006). Sugar maple is often limited by low soil Ca during regeneration (Juice et al. 2006, Sullivan et al. 2013) while its primary mature forest competitor, American beech (Fagus grandifolia Ehrh.; FAGR), appears to be relatively insensitive to the depletion of soil Ca 
65 (Park and Yanai 2009, Duchesne et al. 2013). The desirability of favoring ACSA over FAGR

66 following forest harvest is further emphasized by the effect of beech bark disease (BBD), which

67 greatly reduces the economic value of FAGR.

68 The interaction between ACSA and FAGR following forest harvest has been the subject

69 of considerable research and appears to depend upon both light availability and soil base cation

70 supply. In understory environments FAGR is often favored over ACSA owing to its greater

71 tolerance of low light, whereas ACSA demonstrates a greater response in canopy openings

72 (Canham 1988, Beaudet et al. 1999). In Quebec, clearcut harvesting appeared to give ACSA an

73 advantage over FAGR because of benefits from greater light availability (Nolet et al. 2008,

74 2015). In addition, New Brunswick researchers have found that sites initially dominated by

75 ACSA are likely to regenerate into ACSA-dominated stands post-harvest (Beland and Chicoine

76 2013). However, Bannon et al. (2015) observed that on base-poor soils clearcutting did not favor

77 ACSA over FAGR, suggesting an interaction with soil Ca supply. In contrast, other studies from

78 Canada have demonstrated a high light advantage for ACSA (Nolet et al. 2008, 2015). There is a

79 growing literature debating the efficacy of FAGR control versus Ca amendment in managing for

80 ACSA regeneration (Nolet et al. 2015, Moore et al. 2015).

82 undertaken to evaluate the effects of whole-tree harvest (WTH) on soil nutrient capital and

83 vegetation recovery at a site where detailed budgetary studies using the small-watershed

84 approach indicated substantial depletion of soil base cations during the $20^{\text {th }}$ century (Likens et al.

85 1994). On these experimental watersheds, including Watershed 5 (W5), the subject of this study,

86 soil base cation pools decline significantly at higher elevations owing to thinner, more severely

87 depleted soils (Johnson et al. 2000), creating a natural contrast in soil fertility across the 
landscape. Early surveys following WTH of W5 (Mou et al. 1993) indicated that ACSA, the pre-harvest dominant, exhibited moderately high abundance throughout the regenerating forest. However, on the adjacent uncut reference watershed (W6), ACSA has shown clear signs of recent decline and regeneration failure particularly at higher elevations. The application of $\mathrm{Ca}$ on nearby watershed (W1) in an amount calibrated to replace that lost during the $20^{\text {th }}$ century, largely corrected the decline of ACSA (Juice et al. 2006, Battles et al. 2014). Surveys of tree regeneration at HBEF supported the claim that soil acidification has tipped the competitive balance between ACSA and FAGR towards the latter species (Marlow and Peart 2014, Pontius et al. 2016).

The overall objective of the present study was to evaluate the long-term effects of clearcutting (in this case, whole tree harvesting, WTH) on forest recovery in a northern hardwood watershed. The study takes advantage of two long-term (30-year) surveys of forest composition following WTH of W5 at HBEF. One set of surveys documents the overall forest composition across the complex environmental gradient in this 21.9 ha watershed at scales chosen to accommodate the shifting tree density in the growing forest; the other follows the changes of individual stems mapped at the $0.25 \mathrm{~m}^{2}$ scale, thereby facilitating long-term observation of the outcome of competitive interactions. In conjunction with this vegetation work detailed measurements of soil chemistry were conducted using the quantitative soil pit method across the entire watershed in 1983 (pre-harvest), 1986, 1991 and 1998, providing evidence of treatment effects on soil base cation status. Moreover, a comparison with strip clearcutting on the adjacent watershed (W4; cut in 1970-1974) provides some basis for judging the possible effects of increased harvest intensity associated with WTH on long-term forest recovery. 
The detailed record of repeated observations in the present study provides a robust

111

112

113

114

115

116

117

118

119

120

121

122

123

124

125

126

127

128

129

130

131

132

quantification of patterns as well as limited insights into the underlying processes. In particular,

we can evaluate the extent to which early establishment promotes future species dominance

(Connell and Slatyer 1977, Fukima 2015). These "priority effects" were assumed to be critical to community assembly following WTH. Thus, an emphasis of the W5 study was on understanding the factors that contribute to successful plant colonization (Hughes and Fahey 1991, Mou et al. 1993). Now, 30 years post-harvest, we test this assumption by evaluating the comparative ability of the mature forest dominants, ACSA and FAGR, to hold spaces that they colonized initially. We further investigate the possible modification of any priority effects by an abiotic factor (elevation) and a biotic factor (mode of stem origin: seed, vegetative sprout, advance regeneration). Based on initial patterns of colonization by a mixture of ACSA, FAGR, yellow birch (Betula allegheniensis Britt., BEAL) and a short-lived pioneer, pin cherry (Prunus pensylvanica L., PRPE) (Mou et al. 1993), we expected a similar long-term outcome across most of the watershed owing to priority effects. However, we also expected a combination of high leaching losses and tree nutrient sequestration to deplete soil Ca supplies, especially at the higher elevation zones of the watershed where we hypothesized that FAGR might thereby outperform ACSA. Finally, we hypothesized that these patterns of vegetation recovery would be quantitatively similar on W5 and W4, assuming that the added effects of WTH on nutrient supplies would not be sufficient to drive major differences.

\section{Methods}

Study site. The treated watershed, denoted as W5, is located in the HBEF in central New Hampshire. At the HBEF, precipitation averages 1,395 mm (std. dev. $=189 \mathrm{~mm}$ ) per year, part 
133 of which is captured in snow pack persisting from December until April. The mean annual 134 temperature is $5.5^{\circ} \mathrm{C}\left(\mathrm{std} . \mathrm{dev}=0.61^{\circ} \mathrm{C}\right)$; daily average temperatures range from $-8.5^{\circ} \mathrm{C}$ in January to $18.8^{\circ} \mathrm{C}$ in July (Bailey et al. 2003). The soils are moderately well-drained Spodosols (Haplorthods) and Inceptisols (Dystrochrepts) of sandy-loam texture formed from glacial till.

137 There is a high degree of spatial variability in the experimental watersheds with shallower, more 138 acidic soils at higher elevations (Johnson et al. 2000). These soils exhibit a pattern common in 139 mountainous forest landscapes throughout the Northeastern United States, with low rates of Ca supplied by weathering, and the effects of acidic deposition on soil base status intensifing with 141 increasing elevation (Cho et al. 2012) W5 is 21.9 ha in area and spans an elevation gradient from 488 to $762 \mathrm{~m}$. Our research

143 focused on the lower $85 \%$ of the watershed, which is dominated by species characteristic of the 144 northern hardwood forest, namely ACSA, FAGR and BEAL. Prior to harvest, W5 was gridded 145 into 360 cells, each $25 \mathrm{~m}$ by $25 \mathrm{~m}$ (Fig. S1). Tree composition and size structure were measured 146 prior to harvest in 1982 and then periodically post-harvest starting in 1990 (see Tree surveys).

147 Eight of the 360 cells within the northern hardwood zone were designated as intensive permanent 148 plots to monitor the details of vegetation recovery ("Stem origin plots"; Hughes 1986). During 149 the autumn and winter of 1983-1984, all trees $>2 \mathrm{~cm}$ diameter at breast height (DBH; $1.37 \mathrm{~m})$ 150 were cut. Stems greater than $10 \mathrm{~cm} \mathrm{DBH}$ were removed except trees on the steepest terrain 151 which were cut and dragged off the watershed.

Stem origin plots. Each of the eight stem origin plots $(25 \mathrm{~m}$ by $25 \mathrm{~m})$ was gridded into $153255 \mathrm{~m}$ by $5 \mathrm{~m}\left(25 \mathrm{~m}^{2}\right)$ "sections" (Fig. S1). Twenty-five of the $20025 \mathrm{~m}^{2}$ sections were 154 randomly selected and further divided into $251 \mathrm{~m}^{2}$ permanent plots for intensive study of 155 regeneration $\left(6251 \mathrm{~m}^{2}\right.$ plots total, Fig. S1). In 1983 (pre-harvest), tallies were taken of all stems 
156 in the understory in the $25 \mathrm{~m}^{2}$ sections (Table S1). Stem density in the then-intact forest was 157 relatively low, making it unnecessary to survey at the $1 \mathrm{~m}^{2}$ scale. Following the harvest, soil 158 disturbance and all vegetation (trees, shrubs, herbs) were surveyed at 0.5 x $0.5 \mathrm{~m}$ scale (Hughes 159 1986; Mou et al. 1993). Initial post-harvest patterns were reported previously (Hughes 1986; 160 Hughes and Fahey 1991; Mou et al. 1993). Stems in the stem origin plots were surveyed 13 161 times in the 30 years post-harvest: 1984-1989; 1994-1997; 2001, 2003 and 2014/2015 (Table 162 S1). These detailed plots provided a record of the species and origin of all stems. The origin of 163 each stem was assigned to one of three classes: advance regeneration, vegetative sprout, or seed; 164 advance regeneration was defined as stems established in the understory and present prior to 165 WTH. Sprouts were differentiated by their attachment to stumps or large roots, as well as their 166 thicker bases and lack of cotyledon scars. watershed varied through time to accommodate changes in tree size and stem density. Despite differences in some details, the tree surveys each year were randomly distributed across W5 and always included more than 1,300 individual tree measurements. Prior to harvest, in 1982, all 171 trees $\geq 10 \mathrm{~cm}$ in diameter at breast height $(1.37 \mathrm{~m}, \mathrm{DBH})$ were identified and measured in every

172 grid cell across the entire watershed. Post-harvest, the extent of area sampled and the size of trees 173 measured were designed to capture the variation in the tree community across W5 separately 174 from the stem-origin permanent plots. The first post-harvest tree survey in 1990 defined the tree 175 stratum as trees $\geq 1.5 \mathrm{~cm} \mathrm{DBH}$, and composition and abundance were assessed in 199 transects, 176 each $1 \mathrm{~m}$ by $25 \mathrm{~m}$ in area. The 1994, 1999, and 2004 surveys measured trees $\geq 1.5 \mathrm{~cm} \mathrm{DBH}$ in 177 transects on a random subset (38 in 1994; 101 in 1999 and 2004) of the 360 grid cells. In 2009 178 and 2014, tree surveys consisted of circular plots located in the same 101 grid cells used in 1999 
and 2004, with trees sampled in two size classes; all individuals $\geq 7.5 \mathrm{~cm} \mathrm{DBH}$ were measured in the $100 \mathrm{~m}^{2}$ circular plots, while smaller trees $(1.5 \mathrm{~cm} \leq \mathrm{DBH}<7.5 \mathrm{~cm})$ were measured in a nested $30 \mathrm{~m}^{2}$ transect.

Soil sampling. Soils were sampled before (1983) and 3 yr (1986), 8 yr (1991) and 15 yr (1998) after forest harvest, each time in July. A quantitative pit method, described in detail by Johnson et al. (1991a), was employed, with 9 to 15 pits located randomly across the three hardwood-dominated elevation zones $($ lower $=500-560 \mathrm{~m} ; \mathrm{mid}=560-610 \mathrm{~m}$; upper $=610-670$ m). Several soil layers were separated in the field, with the focus in the present study on the densely-rooted Oa horizon and the $0-10 \mathrm{~cm}$ mineral soil layer. Soil samples were air-dried to constant weight and sieved through either a 5-mm (Oa horizon) or a 2-mm (mineral soil) screen. For determination of exchangeable cations, $2.5 \mathrm{~g}$ of air-dried soil was extracted with $50 \mathrm{~mL}$ of 1 $\mathrm{M} \mathrm{NH}_{4} \mathrm{Cl}$ for $12 \mathrm{~h}$ by mechanical vacuum extraction. Element concentrations in extracts were determined by ICP optical-emission spectrometry.

After the $\mathrm{NH}_{4} \mathrm{Cl}$ extraction, samples were washed with ethanol for $1 \mathrm{~h}$, then extracted with $1 \mathrm{M} \mathrm{KCl}$ for $12 \mathrm{~h}$. Effective cation exchange capacity (CEC) was then determined by analyzing the $\mathrm{KCl}$ extract for $\mathrm{NH}_{4}$ colorimetrically using a continuous-flow analyzer (USEPA, 1983). Percent soil base saturation was calculated as the ratio of the sum of exchangeable base cations to CEC (Johnson et al. 1991b). Effects of sampling year (1983, 1986, 1991, 1998) and elevation zone (low, mid, high) on base saturation and exchangeable Ca were evaluated with a general linear model in Minitab (version 17, Minitab, Inc., State College, PA).

Vegetation analysis. Our vegetation analysis focused on quantifying the factors determining tree establishment and persistence. For context, we provide an overview of the watershed-wide pattern of changes in forest composition. For our more specific questions 
202 regarding the drivers of change, we used generalized linear mixed models where the fixed effects

203 included time since harvest, and the random effects accounted for spatial correlation (Bolker et

204 al. 2009). We also conducted multinomial logistic regression (sensu Augustin et al. 2001) to test

205 the factors that affected the persistence of species after establishment post-harvest. We compared

206

207

208

209

210

211

212

213

214

215

216

217

218

219

220

221

222

223

224

model performance using an information theoretic approach (Burnham and Anderson 2002).

For each model, we calculated Akaike's information criterion (AIC), differences in AIC values relative to the model with the lowest AIC ( $\triangle \mathrm{AIC})$, and AIC weights $\left(\mathrm{w}_{\mathrm{i}}\right)$. Akaike weights $\left(\mathrm{w}_{\mathrm{i}}\right)$ were calculated to normalize the strength of evidence for a given model and can be interpreted as the probability that a given model is the best Kullback-Leibler model for the data given the candidate set of models; models $<2 \Delta \mathrm{AIC}$ have substantial empirical support (Burnham and Anderson 2002). Analyses were conducted using JMP Pro 11 for Windows (SAS Institute. Cary, NC) and the R statistical computing environment version 3.3.0 (R Core Team 2016). Post-harvest changes in density (stems $\mathrm{m}^{-2}$ ) of five species over time (1984-2014) were compared with a linear mixed model. To decrease the number of zero counts, stem counts were averaged from all the $1 \mathrm{~m}^{2}$ stem origin plots surveyed in the section (i.e. seven $25 \mathrm{~m}^{2}$ sections per elevation zone; Table S1). The average density per section was then log transformed to normalize the distribution of residuals. To account for spatial autocorrelation, section was included as a random effect. To account for repeated measures, year was nested within section. The fixed effects were: species ( 5 species), elevation zone (three classes defined as lower, mid and upper, as for soil sampling), year (as a continuous variable; 13 years) and all two and threeway interactions. The trend in stem densities over time suggested that the relationship was quadratic rather than linear; hence, the term year ${ }^{2}$ was also included in the model. The best model was selected from these candidate models using $\triangle \mathrm{AIC}$ and $\mathrm{w}_{\mathrm{i}}$. 
We tested whether initial establishment post-harvest (1984, year 1) predicted future

226 persistence 30 years later $(2014$, year 30$)$. For each of the $1 \mathrm{~m}^{2}$ stem origin plots, we determined

227 the dominant species in 1984, which we refer to as the "winner" species for the plot. Dominance

228 was defined both by stem density and stem origin. In plots showing clear dominance of one

229 species on the basis of stem density that species was assigned as the initial "winner". In plots

230 with similar stem densities for more than one species, the stem origins were used to determine

231 dominance in the order: advance regeneration $>$ sprouts $>$ seedlings to account for size

232 differences between stems of different origin. Using the same criteria, we assigned species

233 dominance in 2014 for each stem origin plot. However, ties in 2014 were determined on the

234 basis of canopy position with field checks in spring 2015; the taller species was assigned the

235 "winner". Some plots in both time periods $(1984,2014)$ were recorded as ties; in these cases,

236 plots had more than a single species assigned as "winner". With these assignments, we calculated

237 the probability of species persistence given successful colonization (i.e. probability that the

238 species that won the plot in 1984 also won the plot in 2014).

Our analysis focused on the species that make-up the mature northern hardwood forest

240 namely ACSA, FAGR, and Betula spp. (BETU). We lumped all the birch species (BEAL; gray

241 birch, Betula populifolia Marsh.; paper birch, B. papyrifera Marsh.; and mountain paper birch, $B$.

242 cordifolia Regel) to genus level because of the difficulty of distinguishing young specimens of

243 these species. Stem origin plots with no tree species present or only pin cherry (PRPE; a pioneer

244 species that rarely persists in the forest past 30 years) were classified as NONE. The class of

245 OTHER species was dominated by striped maple (Acer pensylvanicum L., ACPE), an understory

246 tree species (Hibbs et al. 1980). 
To account for the spatial autocorrelation in the post-harvest recruitment of ACSA and

248

249

250

251

252

253

254

255

256

257

258

259

260

261

262

263

264

265

266

267

268

269

\section{Results}

Prior to harvest, the northern hardwood forest on W5 (Fig. 1) supported on average 26.9 $\mathrm{m}^{2} \mathrm{ha}^{-1}\left(\mathrm{SE}=0.39 \mathrm{~m}^{2} \mathrm{ha}^{-1}\right)$ of live tree basal area. Sugar maple accounted for almost half of the tree basal area (47\%) followed by BETU (25\%, mostly BEAL) and FAGR (20\%). The forest composition varied somewhat among elevation zones (Table 1). Tree density increased with elevation with no detectable change in basal area. The abundance of ACSA, as measured by relative basal area, increased with elevation; BETU declined; and FAGR reached its maximum at higher elevations. Based on the watershed-scale post-harvest surveys the forest had recovered only $21 \%$ of its pre-harvest basal area by 1990 , seven years post-harvest. By 2014, basal area approached pre-harvest levels (Fig. 1A). In contrast, ACSA was a minor component of the postharvest forest, accounting for $<5 \%$ of the basal area (Fig. 1B). In 2014 the forest was dominated by BETU (59\%) and FAGR (16\%).

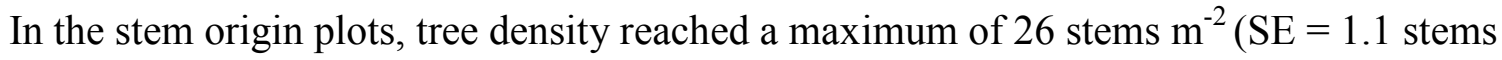
$\mathrm{m}^{-2}$ ) two years (1984) after harvest (Fig. 2A). From this peak, density declined steeply until 


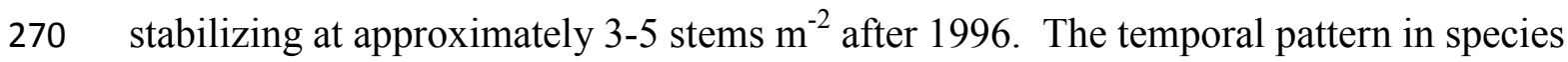

271 composition observed in the watershed-scale surveys was matched by the changes observed in

272 the stem origin plots (Fig. 2B). Specifically, following a transient proliferation and decline in

273 years 1 to 4, relative density of BETU gradually increased from 1987 to 2014; FAGR remained

274 roughly constant through time, and relative density of ACSA declined steadily after 1994. Also

275 evident at both sampling scales was the rapid recruitment response of PRPE post-harvest

276 followed by steady decline. PRPE was the most abundant species in 1987 (Fig. 2B) and

277 accounted for the majority of the live tree basal area in 1990 (59\%, Fig. 1B) but by 2014 PRPE

278 comprised of only one-tenth of the trees as measured by both density (Fig. 2B) and basal area

279 (Fig. 1B).

Despite the similarity in the overall pattern in tree density with time since harvest, there

282 support $\left(\mathrm{w}_{\mathrm{i}}=1\right)$ for the full statistical model of tree density that included a quadratic response by

283 year and interactions among species, elevation class, and year (Table S2). The influence of

284 elevation class on abundance was particularly striking for ACSA. Using the parameters from the

285 best model of tree density, we estimated the trend in tree density after harvest for the dominant

286 species (ACSA, FAGR, BETU) in each elevation class (Fig. 4). While as expected the density

287 declined over time for all species at all elevations, the decrease in density for ACSA was greatest 288 at upper elevation and least at lower elevation.

289 Both elevation class and distance from the base of the watershed influenced the

290 probability of persistence of stems established in 1984. Both the best model (\#4 in Table S3, $\mathrm{w}_{\mathrm{i}}=$ $2910.56)$ and the second best model $\left(\# 10, \mathrm{w}_{\mathrm{i}}=0.43\right)$ included elevation class and distance. To 292 examine the species differences, we predicted persistence probabilities using the best model. 
293 Overall, the probability that a plot that was won by ACSA in 1984 was still dominated by ACSA 294 in 2014 was 0.16 (Table 2). In contrast, FAGR had a probability of 0.70 of retaining dominance. 295 Sugar maple persistence was strongly related to elevation with the probability of persistence 296 declining sharply with elevation (Table 2). American beech persistence also was reduced in the 297 upper elevation class. BETU won relatively few plots in 1984 but in 2014 dominated most of the 298 plots at the upper elevation. The coefficients for the distance term suggest spatial autocorrelation 299 for persistence probability of ACSA and FAGR but not for BETU.

The lack of persistence in plots won by ACSA in 1984 was not entirely driven by 301 replacement by another species. For example, of the plots won by ACSA in 1984, the probability of FAGR winning in 2014 was 0.37 while the next most common fate (probability $=0.31$ ) was that the plot simply remained unoccupied or was temporarily held by PRPE (NONE; Table 2). Immediately post-harvest, the origin of stems varied by species. Most of the BETU 305 initiated from seed. The majority (55\%) of ACSA stems also grew from seeds, with sprouting 306 accounting for only $16 \%$ of the recruits. In contrast, $65 \%$ of the FAGR stems originated from 307 sprouts, with only $13 \%$ beginning as seeds. for ACSA but not for FAGR. For the subset of plots won by ACSA in $1984(\mathrm{n}=175)$, the best

310 model (\#6; Table S4) included only origin $\left(\mathrm{w}_{\mathrm{i}}=0.72\right)$. Based on predictions from the best 311 model, stems that originated as sprouts had the highest probability of persistence in $2014(0.32)$

312 followed by advance regeneration (0.12) and then seeds (0.03). In contrast, origin was not 313 included in the best model (\#3) for the subset of plots won by FAGR in $1984(\mathrm{n}=117$, Table 314 S5). 
Surface soil chemistry in the hardwood forest varied both across years and elevation

316

317

318

319

320

321

322

323

324

325

326

327

328

329

330

331 332 factors.

333

334

335

336

337

zones (Table 3). In particular, exchangeable $\mathrm{Ca}$ in the Oa horizon differed significantly both among elevation zones and sampling years (Table S6), with lowest values in the upper elevation zone in post-harvest years (Table 3). Base saturation also was lowest in the upper elevation zone post-treatment, but the year effect was not significant. No significant year by treatment interactions were detected for either base saturation or exchangeable Ca. Although patterns for the $0-10 \mathrm{~cm}$ mineral soil were similar, with the lowest values post-harvest in the upper elevation zone (Table 3), none of the effects was statistically significant (Table S6).

\section{Discussion}

Recovery of the northern hardwood forest following WTH of W5 at the HBEF demonstrated sustained capacity for growth in basal area but a striking change in species composition through 30 years. Most importantly for ACSA, the dominant species prior to treatment, initially high abundance was followed by a drastic decline in relative density and basal area so that ACSA has been relegated to be a minor species in the recovering forest (Figs 1 and 2). Detailed observations in permanent plots indicated that the decline in abundance of ACSA was associated with a combination of biotic (competition from FAGR) and abiotic (elevation)

Overall, FAGR was four times as likely as ACSA to persist as the dominant species in a location (Table 2). Intriguingly, ACSA was almost as likely to lose its spot to FAGR as for the spot to become unoccupied. This observation supports the hypothesis of Kardol et al. (2013) that priority effects for some species (in this case ACSA) may be weakened on infertile soils and suggests that ACSA was limited not only by competition with FAGR and BETU, but also by 
338 abiotic factors (probably low soil $\mathrm{Ca}$ ). Elevation was the strongest modifier of priority effects, weakening these effects for both ACSA and FAGR and allowing the eventual domination of upper elevation by BETU, which came in a year after harvest (Fig. 3) following high seed production in 1985 .

Although we cannot conclusively disentangle elevation-based climatic and soil effects in driving the performance of ACSA on W5, it is likely that the thin, base-poor soils in the upper elevations played a primary role. The elevation range of the northern hardwood forest on W5 (500-660 m) falls squarely within the climatic envelope of ACSA (Canham and Murphy 2016). Regeneration of ACSA is clearly limited by low soil Ca availability at the HBEF, as illustrated by observations from an adjacent watershed (W1), where experimental replacement of Ca lost as a result of human activity in the $20^{\text {th }}$ century corrected both regeneration failure (Juice et al. 2006) and mature ACSA growth and health (Battles et al. 2014). Thus, the correspondence between poor performance of ACSA (Fig. 2) and low soil base saturation and exchangeable Ca concentration in surface soils in upper elevation zones (Table 3) is likely a causal relationship. The finding that forest clearcutting, which increases light availability dramatically, did not favor ACSA over FAGR agrees with observations made by Bannon et al. (2015) on sites poor in base cations in Quebec. Our study lends further support for a threshold of soil base saturation or exchangeable Ca for successful ACSA regeneration (Sullivan et al. 2013). Thus, without soil amendments, efforts to remove the beech sapling layer may not lead to successful regeneration of ACSA on acidified soils. In contrast, on richer sites control of FAGR often will be necessary for the successful regeneration of ACSA following harvest (Nolet et al. 2008, 2015). 
For ACSA, low survival of seedlings emphasized the importance of maintaining sprouts

361

362

and advance regeneration in forest management activities. Sugar maple seedlings would draw their nutrients largely from the organic soil horizons. It is notable therefore that these low seedling survival rates coincided with significant decreases in exchangeable Ca concentrations and base saturation in Oa horizon soils, especially in mid- and upper-elevation hardwood zones (Tables 3, S6). Johnson et al. (1997) noted that losses of cations from upper soil horizons on W5 would lead to an advantage for growth of advance regeneration and sprouts as they have roots that penetrate to deeper soil layers. This may also be part of the mechanism explaining the greater ability of FAGR to persist in sites where it established because $65 \%$ of the initial stems were sprouts.

Widespread dieback of ACSA has been associated with nutrient stress throughout its northern range (Bal et al. 2015), and Ca limitation of ACSA regeneration, growth and health has been commonly observed on base-poor and Ca-depleted soils (Long et al. 1997; Schaberg et al. 2006; Battles et al. 2014). Further depletion of soil Ca pools and availability associated with forest harvest is likely to result in reduced abundance and growth of ACSA in post-harvest stands on acidified soils. In New England, the problems for ACSA are particularly severe at higher elevations (Juice et al. 2006, Pontius et al. 2016) primarily because of thinner, base-poor soils. Notably, ACSA often thrives near its elevation limits (ca. $800 \mathrm{~m}$ at Hubbard Brook) on base-rich soils (S. Bailey, personal observation). Thus, potential upward expansion of the elevation range of ACSA in a warming climate is likely to be constrained by low soil base status associated with natural edaphic patterns, limited competitive ability for mineral nutrient acquisition in conifer-dominated areas (Collin et al. 2017), and with depletion by atmospheric deposition and forest management. 
The WTH treatment on W5 was motivated in part by concern that nutrient removal by the

practice might represent a greater threat to soil fertility and forest recovery than conventional harvest (Weetman and Webber 1972). Long-term observations following strip clearcutting of the adjacent W4 at HBEF (Thurston et al. 1992, A. Bailey, unpublished data) indicate less extreme but qualitatively similar regeneration results as for W5. In particular, on a watershedwide basis relative basal area of ACSA on W4 prior to harvest averaged $30 \%$ and was $8 \%$ at 30 yr post-harvest (compared with W5: 47\% pre-harvest and 5\% after $30 \mathrm{yr}$ ). Notably, ACSA had the most severely reduced abundance in the higher elevation zone of W4 similar to the pattern we observed on W5. Therefore, although the strip clearcutting on W4 resulted in less removal of base cations from the site both as timber products (only boles were removed) and in stream water (Hornbeck et al. 1986), soil nutrient depletion was apparently still sufficient to limit the success of ACSA.

Our observations raise an intriguing question: what explains the high abundance of ACSA on the naturally base-poor soils of HBEF, especially at higher elevations where its regeneration and regrowth are clearly impaired (Battles et al. 2014, Fig. 4)? Regional

398 comparisons of historic and modern forest composition indicate that the abundance of ACSA 399 greatly increased between pre-settlement (early $19^{\text {th }}$ century) and modern times in mid-elevation 400 zones of the northeastern US mountains (Siccama 1971, Vadeboncouer et al. 2013) similar to 401 HBEF. This increase coincided with a dramatic decline in the abundance of red spruce (Picea 402 rubens Sarg.) owing in part to intensive logging for this species in the $19^{\text {th }}$ century. At the 403 HBEF, historical records (C.V. Cogbill, personal communication) indicate selective logging of 404 red spruce in the late $19^{\text {th }}$ century, followed by heavy cutting of all merchantable trees between $405 \quad 1908-1920$ and some salvage cutting following blowdown by the 1938 hurricane (van Doorn et 
406

407

408

409

410

411

412

413

414

415

416 from FAGR.

417

418

419

420

421

422

\section{Acknowledgments}

424 The 1983-1989 surveys on the stem origin plots were led by Jeffrey Hughes and Mou Pu; 1994-

425 1997, 2001 surveys were led by Anna Stalter; 2003 by Michael White and 2014-2015 by NLC.

426 The tree surveys were led by Tom Siccama in 1982, 1990, 1994 and 1999; by Michael White in

427 2004; by Natalie van Doorn and JJB in 2009; and by NLC in 2014. Amey Bailey, USDA Forest

428 Service, provided tree inventories for watershed 4 at HBEF. This project was funded by grants 
429 from the National Science Foundation (NSF) and is a contribution to the Hubbard Brook

430 Ecosystem Study. Hubbard Brook is part of the Long-term Ecological Research (LTER)

431 network, which is supported by NSF. The HBEF is operated and maintained by the USDA

432 Forest Service, Northern Research Station, Newtown Square, PA, U.S.

433

434 References

435 Augustin, N.H., Cummins, R.P. and French, D.D. 2001. Exploring spatial vegetation dynamics

436 using logistic regression and a multinomial logit model. J. Appl. Ecol. 38(5): 991-1006.

437 Bailey, A.S., Hornbeck, J.W., Campbell, J.J., and Eagar, C. 2003. Hydrometeorological

438 database for Hubbard Brook Experimental Forest: 1955-2000. Gen. Tech. Rep. GTR-NE-305.

439 Bal, T.L., Storer, A.J., Jurgensen, M.F., Doskey, P.V., and Amacher, M.C. 2015. Nutrient stress

440 predisposes and contributes to sugar maple dieback across its northern range: a review.

441 Forestry (Lond) 88(1): 64-83. Doi: 10.1093/forestry/cpu051.

442 Bannon, K., Delagrange, S., Bélanger, N., and Messier, C. 2015. American beech and sugar

443 maple sapling relative abundance and growth are not modified by light availability following

444 partial and total canopy disturbances. Can. J. For. Res. 45:632-638. doi: org/10.1139/cjfr-

$445 \quad 2014-0240$.

446 Battles, J.J., Fahey, T.J., Driscoll, C.T., Blum, J.D., and Johnson, C.E. 2014. Restoring soil

447 Calcium reverses forest decline. Environ. Sci. Technol. Lett. 1: 15-19.

448 doi:10.1021/ez400033d.

449 Beaudet, M., Messier, C., Pare, D., Brisson, J., and Bergeron, Y. 1999. Possible mechanisms of 450 sugar maple regeneration failure and replacement by beech in the Boise-des-Muir old-growth 451 forest, Quebec. Ecoscience, 6(2): 264-271. 
452 Beland, M., and Chicoine, B. 2013. Tolerant hardwood natural regeneration 15 years after 453 various silvicultural treatments on an industrial freehold of northwestern New Brunswick. 454 For. Chron. 89(4):512-524. doi: 10.5558/tfc2013-092.

455 Bolker, B.M., Brooks, M.E., Clark, C.J., Geange, S.W., Poulsen, J.R., Stevens, M.H.H. and 456 White, J.S.S. 2009. Generalized linear mixed models: a practical guide for ecology and 457 evolution. Trends Ecol. Evol. 24(3):127-135.

458 Bormann, F.H., Likens, G.E., and Eaton, J.S. 1969. Biotic regulation of particulate and solution 459 losses from a forest ecosystem. BioScience 19(7): 600-610.

460 Bormann, F.H., Siccama, T.G., Likens, G.E. and Whittaker, R.H., 1970. The Hubbard Brook 461 ecosystem study: composition and dynamics of the tree stratum. Ecol. Monogr. 40(4):373462388.

463 Burnham, K.P., and Anderson, D.R. 2002. Model Selection and Mutlimodel Inference: A 464 Practical Information-Theoretic Approach. Springer, New York.

465 Canham, C.D. 1988. Growth and canopy architecture of shade-tolerant trees: response to canopy 466 gaps. Ecology 69(3): 786-795.

467 Canham, C.D., and Murphy, L. 2016. The demography of tree species response to climate: 468 sapling and canopy tree growth. Ecosphere 7(10): e01474. 10.1002/ecs2.1474.

469 Caputo, J., Beier, C.M., Sullivan, T.J., and Lawrence, G.B. 2016. Modeled effects of soil 470 acidification on long-term ecological and economic outcomes for managed forests in the 471 Adirondack region (USA). Sci. Total Environ. 565:401-411.

472 doi:10.1016/j.scitotenv.2016.04.008. 
CJFR-2017-0233

473 Cho, Y., Driscoll, C.T., Johnson, C.E., Blum, J.D., and Fahey, T.J. 2012. Watershed-level

474 responses to calcium silicate treatment in a northern hardwood forest. Ecosystems 15:416-

475434.

476 Connell, J.H., and Slatyer, R.O. 1977. Mechanisms of succession in natural communities and

477 their role in community stability and organization. Am. Nat. 111(982):1119-1144.

478 Collin, A., Messier, C., and Belanger, N. 2017. Conifer presence may negatively affect sugar

479 maple's ability to migrate into the boreal forest through reduced foliar nutritional status.

$480 \quad$ Ecosystems 20(4): 701-716.

481 Duchesne, L., and Ouimet, R. 2009. Present-day expansion of American beech in northeastern

482 hardwood forests: Does soil base status matter? Can. J. For. Res. 39: 2273-2282.

483 Duchesne, L., Moore, J.-D., and Ouimet, R. 2013. Partitioning the Effect of Release and Liming 484 on Growth of Sugar Maple and American Beech Saplings. North. J. Appl. For. 30: 28-36.

485 Fahey, T.J. and Blum, J.D. 2011. Litter layers $\left(\mathrm{O}_{\text {ie }}\right)$ as a calcium source of sugar maple

486 seedlings in a northern hardwood forest. Can. J. For. Res. 41(4): 898-901.

487 Federer, C.A., Hornbeck, J.W., Tritton, L.M., Martin, C.W., Pierce, R.S., and Smith, C.T. 1989.

488 Long-term depletion of calcium and other nutrients in eastern US forests. Environ.

489 Manage.13(5), 593-601.

490 Fukami, T. 2015. Historical contingency in community assembly: Integrating niches, species

491 pools, and priority effects. Annu. Rev. Ecol. Evol. Syst. 46:1-23.

492 Hibbs, D.E., Wilson, B.F., and Fischer, B.C. 1980. Habitat requirements and growth of striped

493 maple (Acer pensylvanicum L.). Ecology 61:490-496. 
494 Hornbeck, J.W., Martin, C.W., Pierce, R.S., Bormann, F.H., Likens, G.E., and Eaton, J.S. 1986.

495 Clearcutting northern hardwoods: effects on hydrologic and nutrient ion budgets. For. Sci.

$496 \quad 32(3): 667-686$.

497 Hughes, J.W. 1986. Maintenance of floristic patterns in a disturbed northern hardwood forest:

498 regeneration strategies and forest history. PhD Dissertation, Department of Natural Resources,

499 Cornell University, Ithaca, New York

500 Hughes, J.W., and Fahey, T.J. 1991. Colonization dynamics of herbs and shrubs in a disturbed

501 northern hardwood forest. J. Ecol. 79:605-616.

502 Johnson, C.E., Johnson, A.H., Huntington, T.G., and Siccama, T.G. 1991a. Whole-tree clear-

503 cutting effects on soil horizons and organic-matter pools. Soil Sci. Soc. Am. J. 55(2):497-502.

504 Johnson, C.E., Johnson, A.H., and Siccama, T.G. 1991b. Whole-tree clear-cutting effects on 505 exchangeable cations and soil acidity. Soil Sci. Soc. Am. J. 55(2):502-508.

506 Johnson, C.E., Romanowicz, R.B. and Siccama, T.G. 1997. Conservation of exchangeable

507 cations after clear-cutting of a northern hardwood forest. Can. J. For. Res. 27(6):859-868.

508 Johnson, C.E., Driscoll, C.T., Siccama, T.G. and Likens, G.E. 2000. Element fluxes and

509 landscape position in a northern hardwood forest watershed ecosystem. Ecosystems 3(2): 159-

$510 \quad 184$.

511 Juice, S.M., Fahey,T.J., Siccama, T.G., Driscoll, C.T., Denny, E.G., Eagar, C., Cleavitt, N.L.,

512 Minocha, R., and Richardson, A.D. 2006. Response of sugar maple to calcium addition to

513 northern hardwood forest at Hubbard Brook, NH. Ecology 87(5):1267-1280.

514 Junge, C.E., and Werby, R.T. 1958. The concentration of chloride, sodium, potassium, calcium, 515 and sulfate in rain water over the United States. J. Meteorology 15(5): 417-425. 
516

517

518

519

520

521

522

523

524

525

526

527

528

529

530

531

532

533

534

535

536

537

538

Kardol, P., Souza, L., and Classen, A.T. 2013. Resource availability mediates the importance of priority effects in plant community assembly and ecosystem function. Oikos, 122(1):84-94.

Likens, G.E., Driscoll, C.T., Buso, D.C., Siccama, T.G., Johnson, C.E., Lovett, G.M., Fahey, T.J., Reiners, W.A., Ryan, D.F., Martin, C.W. and Bailey, S.W. 1998. The biogeochemistry of calcium at Hubbard Brook. Biogeochem. 41(2): 89-173.

Long, R.P., Horsley, S.B., and Lilja, P.R. 1997. Impact of forest liming on growth and crown vigor of sugar maple and associated hardwoods. Can. J. For. Res. 27(10): 1560-1573.

Mann, L.K., Johnson, D.W., West, D.C., Cole, D.W., Hornbeck, J.W., Martin, C.W., Riekerk, H., Smith, C.T., Swank, W.T., Tritton, L.M,. and Van Lear, D.H. 1988. Effects of whole-tree and stem-only clearcutting on postharvest hydrologic losses, nutrient capital, and regrowth. For. Sci. 34(2): 412-428.

Marlow, J., and Peart, D.R. 2014. Experimental reversal of soil acidification in a deciduous forest: implications for seedling performance and changes in dominance of shade-tolerant species. For. Ecol. Manage. 313: 63-68. doi:10.1016/j.foreco.2013.10.036.

Moore, J-D., Camiré, C., and Ouimet, R. 2000. Effects of liming on the nutrition, vigor, and growth of sugar maple at the Lake Clair Watershed, Quebec, Canada. Can. J. For. Res. 30(5): $725-732$.

Moore, J-D., Ouimet, R., Long, R.P., and Bukaveckas, P.A. 2015. Ecological benefits and risks arising from liming sugar maple dominated forests in northeastern North America. Environ. Rev.23: 66-77. dx.doi.org/10.1139/er-2014-0048.

Mou, P., Fahey, T.J., and Hughes, J.W. 1993. Effects of soil disturbance on vegetation recovery and nutrient accumulation following whole-tree harvest of a Northern Hardwood Ecosystem.

J. Appl. Ecol. 30(4):661-675. 
539

540

541

542

543

544

545

546

547

548

549

550

551

552

553

554

555

556

557

558

559

560

561

Nelson, A.S., and Wagner, R.G. 2014. Spatial coexistence of American beech and sugar maple regeneration in post-harvest northern hardwood forests. Ann. For. Sci. 71(7):781-789. doi: 10.1007/s13595-014-0376-2.

Nolet, P., Bouffard, D., Doyon, F., and Delagrange, S. 2008. Relationship between canopy disturbance history and current sapling density of Fagus grandifolia and Acer saccharum in a northern hardwood landscape. Can. J. For. Res. 38(2):216-225. doi: 10.1139/X07-160.

Nolet, P., Delagrange, S., Bannon, K., Messier, C., and Kneeshaw, D. 2015. Liming has a limited effect on sugar maple - American beech dynamics compared with beech sapling elimination and canopy opening. Can. J. For. Res. 45(10):1376-1386. doi: 10.1139/cjfr-2015-0010.

Park, B.B., and Yanai, R.D. 2009. Nutrient concentrations in roots, leaves and wood of seedling and mature sugar maple and American beech at two contrasting sites. For. Ecol. Manage. 258(7):1153-1160. doi: 10.1016/j.foreco.2009.06.003.

Pontius, J., Halman, J.W., and Schaberg, P.G. 2016. Seventy years of forest growth and community dynamics in an undisturbed northern hardwood forest. Can. J. For. Res. 46: 959967. dx.doi.org/10.1139/cjfr-2015-0304.

R Core Team. 2016. R: A language and environment for statistical computing. R Foundation for Statistical Computing, Vienna, Austria. URL: https://www.R-project.org/.

Rennie, P.J. 1955. The uptake of nutrients by mature forest growth. Plant Soil 7(1): 49-95.

Schaberg, P.G., Tilley, J.W., Hawley, G.J., DeHayes, D.H., and Bailey, S.W. 2006. Associations of calcium and aluminum with the growth and health of sugar maple trees in Vermont. For. Ecol. Manage. 223(1):159-169.

Siccama, T.G. 1971. Presettlement and present forest vegetation in northern Vermont with special reference to Chittenden County. Am. Midland Naturalist 85:153-172. 
CJFR-2017-0233

562 Sullivan, T.J., Lawrence G.B., Bailey, S.W., McDonnell, T.C., Beier, C.M., Weathers, K.C.,

563 McPherson, G.T., and Bishop, D.A. 2013. Effects of acidic deposition and soil acidification

564 on sugar maple trees in the Adirondack Mountains, New York. Environ. Sci. Technol.

565 47:12687-12694. dx.doi.org/10.1021/es401864w.

566 Thurston, S. W., Krasny, M. E., Martin, C. W., \& Fahey, T. J. (1992). Effect of site

567 characteristics and 1st-and 2nd-year seedling densities on forest development in a northern

568 hardwood forest. Can. J. For. Res. 22(12): 1860-1868.

569 US EPA. 1983. Methods for chemical analysis of water and wastes. USEPA-600/4-79-020.

570 Environmental Monitoring and Support Laboratory, Cincinnati, $\mathrm{OH}$.

571 Vadeboncoeur M.A., Hamburg, S.P., Yanai, R.D., and Blum, J.D. 2014. Rates of sustainable

572 forest harvest depend on rotation length and weathering of soil minerals. For. Ecol. Manage.

$573 \quad 318: 194-205$.

574 Van Doorn, N.S., Battles, J.J., Fahey, T.J., Siccama, T.G., and Schwarz, P.A. 2011. Links

575 between biomass and tree demography in a northern hardwood forest: a decade of stability

576 and change in Hubbard Brook Valley, New Hampshire. Can. J. For. Res. 41(7):1369-1379.

577 Weetman, G.F., and Webber, B. 1972. The influence of wood harvesting on the nutrient status of

578 two spruce stands. Can. J. For. Res. 2(3): 351-369. 
Table 1. Elevational gradient in pre-harvest forest composition (A) and species distribution (B) in Watershed 5 at Hubbard Brook Experimental Forest, NH. Means and standard errors (se) reported for each elevation zone; $\mathrm{n}$ represents the number of tree survey plots in each zone. Species distribution reported as relative basal area.

\begin{tabular}{|c|c|c|c|c|c|c|}
\hline \multirow[t]{2}{*}{ A. Forest composition } & \multicolumn{3}{|c|}{$\begin{array}{l}\text { Basal area } \\
\left(\mathrm{m}^{2} \mathrm{ha}^{-1}\right)\end{array}$} & & \multicolumn{2}{|c|}{$\begin{array}{c}\text { Density } \\
\left(\text { stems ha }^{-1}\right)\end{array}$} \\
\hline & $\mathrm{N}$ & mean & se & & mean & se \\
\hline Lower hardwood & 49 & 27.3 & 0.8 & & 425 & 14 \\
\hline Mid hardwood & 67 & 27.3 & 0.8 & & 424 & 13 \\
\hline Upper hardwood & 79 & 26.8 & 0.6 & & 518 & 17 \\
\hline B. Relative basal area & & $\mathrm{ACPE}$ & ACSA & BETU & FAGR & PRPE \\
\hline Lower hardwood & & 0.00 & 0.40 & 0.32 & 0.17 & 0.00 \\
\hline Mid hardwood & & 0.00 & 0.48 & 0.25 & 0.20 & 0.00 \\
\hline Upper hardwood & & 0.01 & 0.51 & 0.22 & 0.20 & 0.00 \\
\hline
\end{tabular}


Table 2. Predicted persistence probabilities by species and by elevation class for Watershed 5 at Hubbard Brook Experimental Forest, NH. For these estimates, distance set to the mean.

\begin{tabular}{|c|c|c|c|c|c|c|}
\hline \multirow{2}{*}{ Low } & & \multicolumn{5}{|c|}{ Winners in 2014} \\
\hline & & ACSA & BETU & FAGR & NONE & OTHER \\
\hline \multirow{5}{*}{ 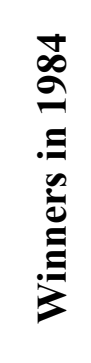 } & ACSA & 0.39 & 0 & 0.15 & 0.30 & 0.16 \\
\hline & BETU & 0.13 & 0 & 0.26 & 0.41 & 0.20 \\
\hline & FAGR & 0.16 & 0 & 0.50 & 0.23 & 0.11 \\
\hline & NONE & 0 & 0 & 0 & 1 & 0 \\
\hline & OTHER & 0.39 & 0 & 0.18 & 0.30 & 0.13 \\
\hline \multicolumn{2}{|l|}{ Mid } & ACSA & BETU & FAGR & NONE & OTHER \\
\hline \multirow{5}{*}{ 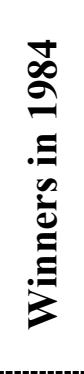 } & ACSA & 0.09 & 0.21 & 0.27 & 0.39 & 0.04 \\
\hline & BETU & 0.01 & 0.54 & 0.20 & 0.22 & 0.02 \\
\hline & FAGR & 0.02 & 0.27 & 0.52 & 0.17 & 0.01 \\
\hline & NONE & 0 & 0.74 & 0 & 0.26 & 0 \\
\hline & OTHER & 0.08 & 0.28 & 0.28 & 0.34 & 0.03 \\
\hline \multicolumn{2}{|c|}{ Upper } & ACSA & BETU & FAGR & NONE & OTHER \\
\hline \multirow{5}{*}{ 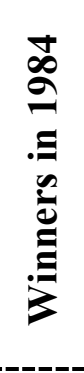 } & ACSA & 0 & 0.98 & 0.01 & 0.02 & 0 \\
\hline & BETU & 0 & 0.99 & 0 & 0 & 0 \\
\hline & FAGR & 0 & 0.98 & 0.01 & 0.01 & 0 \\
\hline & NONE & 0 & 1 & 0 & 0 & 0 \\
\hline & OTHER & 0 & 0.98 & 0.01 & 0.01 & 0 \\
\hline \multicolumn{2}{|l|}{ All } & ACSA & BETU & FAGR & NONE & OTHER \\
\hline \multirow{5}{*}{ 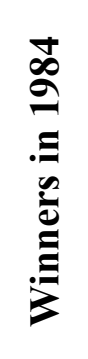 } & ACSA & 0.16 & 0.06 & 0.37 & 0.31 & 0.09 \\
\hline & BETU & 0.04 & 0.19 & 0.43 & 0.27 & 0.07 \\
\hline & FAGR & 0.04 & 0.08 & 0.70 & 0.14 & 0.03 \\
\hline & NONE & 0 & 0.47 & 0 & 0.53 & 0 \\
\hline & OTHER & 0.14 & 0.07 & 0.45 & 0.25 & 0.08 \\
\hline
\end{tabular}


Table 3. Soil base saturation and exchangeable calcium concentration in three elevation zones and two soil horizons on Watershed 5 at the Hubbard Brook Experimental Forest, NH before (1983) and after (average for 1986,1991,1998) whole tree harvest. Results of general linear model for elevation and treatment effects can be found in Table S6.

\begin{tabular}{lccccc}
\hline \multicolumn{1}{c}{$\begin{array}{c}\text { Elevation } \\
\text { Zone }\end{array}$} & Soil depth & \multicolumn{2}{c}{$\begin{array}{c}\text { \% } \\
\text { (cmol } / \mathbf{k g}) \\
\end{array}$} & & \multicolumn{2}{c}{$\begin{array}{c}\text { Base saturation } \\
\text { Pre-trt }\end{array}$} & Post-trt & \multicolumn{2}{c}{$\begin{array}{c}\text { Exchangeable Ca } \\
\text { Pre-trt }\end{array}$} & \begin{tabular}{c} 
Post-trt \\
\hline Lower
\end{tabular} & $\mathrm{Oa}$ & 56.6 & 53.1 & 8.43 & 7.41 \\
hardwood & $0-10 \mathrm{~cm}$ & 14.0 & 18.0 & 0.89 & 0.96 \\
\hline Mid & $\mathrm{Oa}$ & 47.3 & 44.6 & 6.78 & 4.83 \\
hardwood & $0-10 \mathrm{~cm}$ & 14.4 & 16.9 & 0.79 & 1.02 \\
\hline Upper & $\mathrm{Oa}$ & 53.7 & 40.4 & 7.89 & 4.61 \\
hardwood & $0-10 \mathrm{~cm}$ & 15.7 & 14.4 & 0.98 & 0.89 \\
\hline
\end{tabular}




\section{Figure Legends}

Figure 1. Shift in (A) total basal area and (B) relative basal area of most common tree species prior to and following whole tree harvest on Watershed 5 at Hubbard Brook Experimental Forest, NH. Data from tree surveys.

Figure 2. Changes in $(\mathbf{A})$ tree density and $(\mathbf{B})$ relative abundance of the most common tree species following whole-tree harvest on Watershed 5 at Hubbard Brook Experimental Forest, NH. Data from stem origin plots.

Figure 3. Trajectory of recovery in three elevation classes for sugar maple (ACSA), American beech (FAGR), birch species (BETU) and other species (mainly pin cherry and striped maple) for the first 30 years after whole-tree harvest on Watershed 5 at Hubbard Brook Experimental Forest, NH. Data from stem origin plots.

Figure 4. Modelled predictions of stem density change for sugar maple (ACSA), American beech (FAGR) and birch species (BETU) to illustrate species interactions with elevation class. 

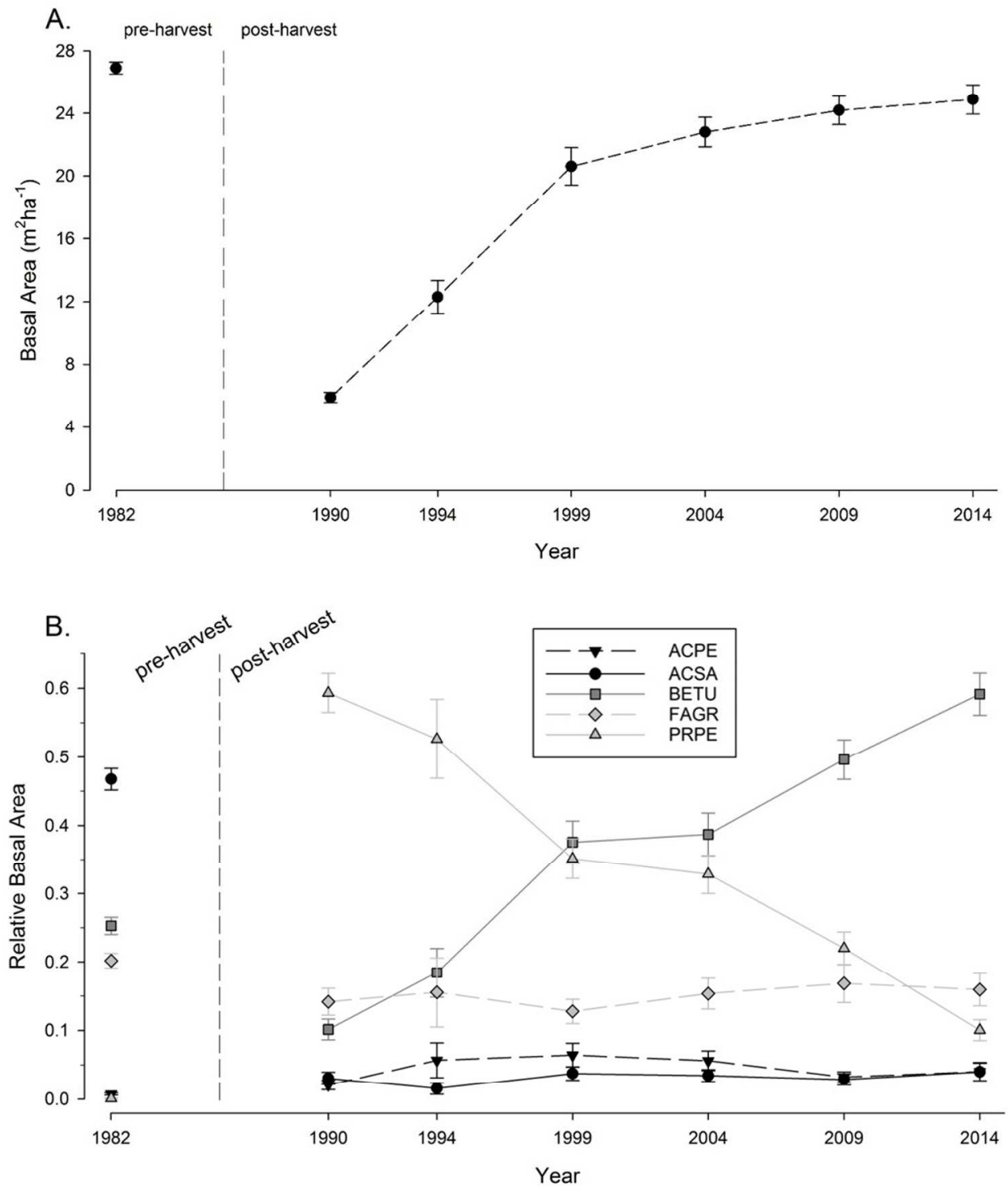

Figure 1

$184 \times 210 \mathrm{~mm}(150 \times 150 \mathrm{DPI})$ 

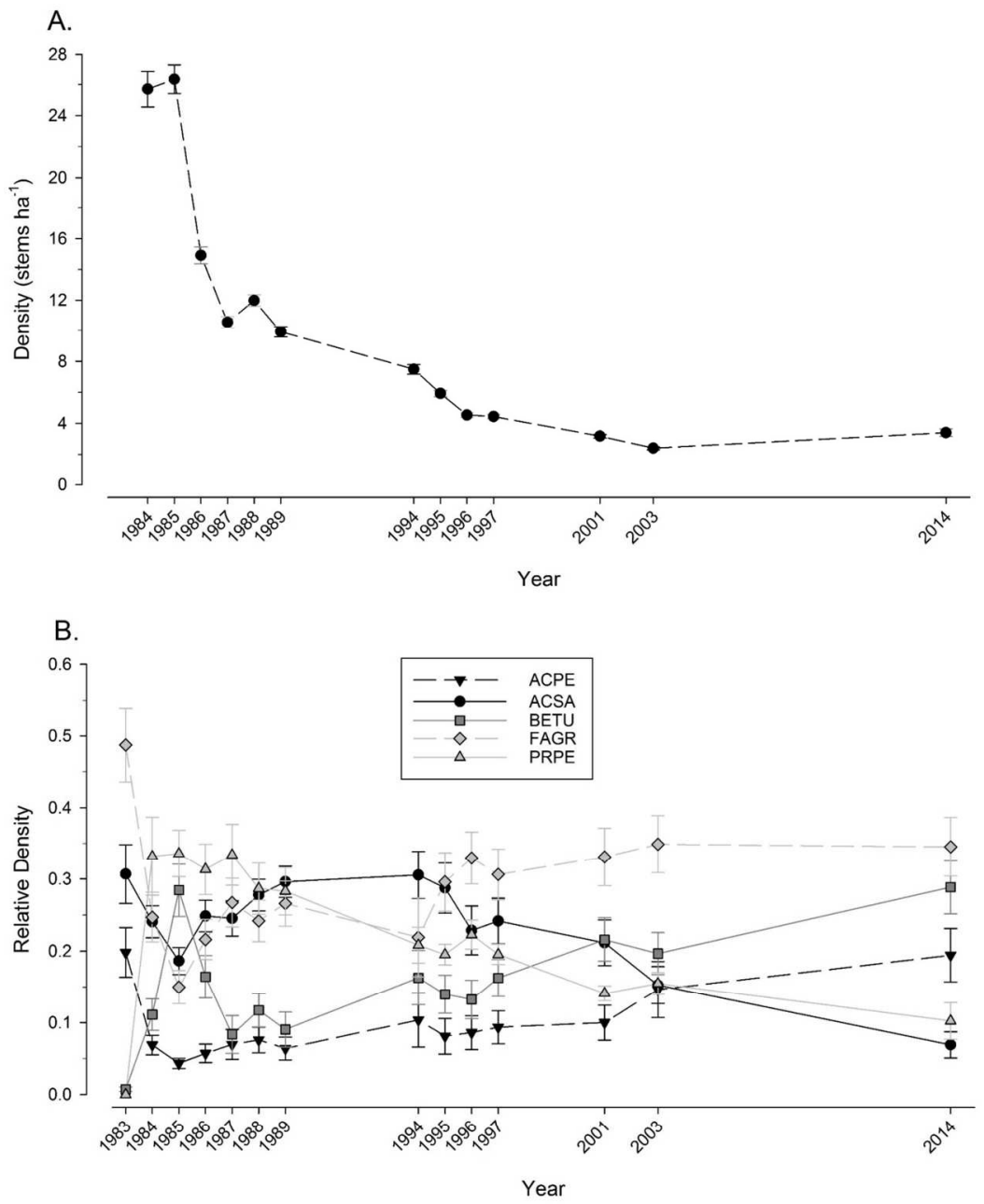

Figure 2

$254 \times 338 \mathrm{~mm}(300 \times 300$ DPI) 


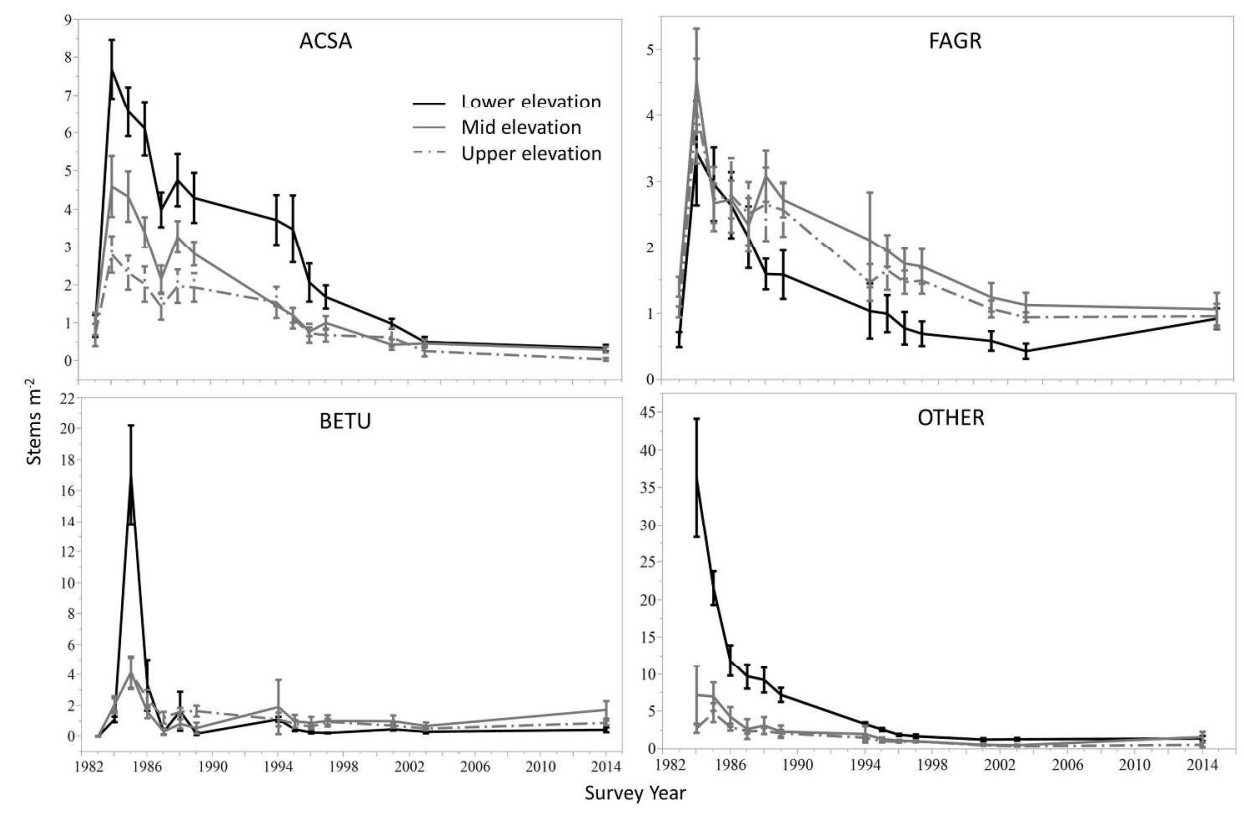

Figure 3

$337 \times 253 \mathrm{~mm}(231 \times 231 \mathrm{DPI})$ 


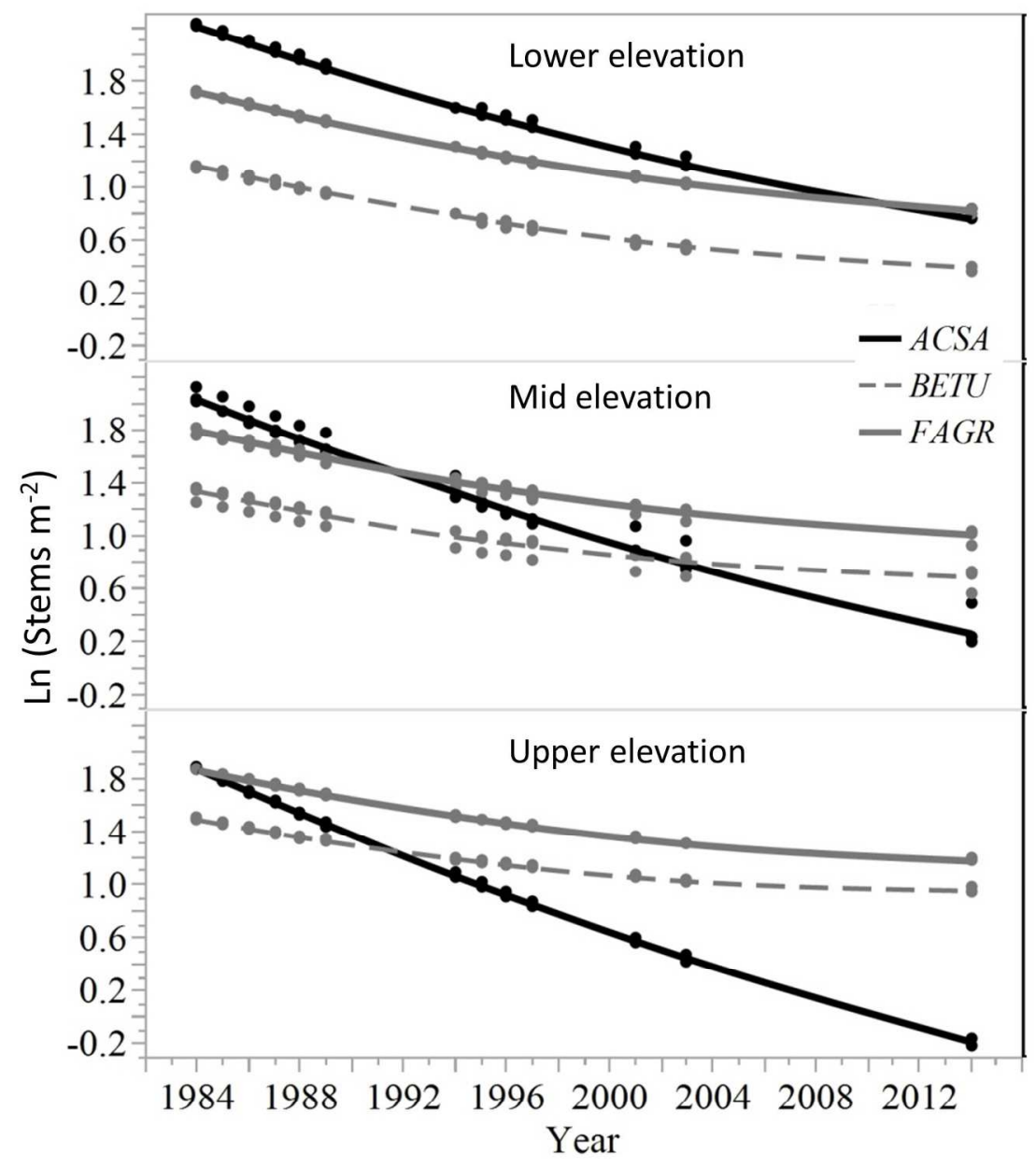

Figure 4

$254 \times 338 \mathrm{~mm}(300 \times 300$ DPI $)$ 
Table S1. Ranking of density models for $5 \mathrm{~m}^{2}$ sections $(n=21)$. Best model identified with bold text.

\begin{tabular}{clcccc}
\hline Model number & Model terms & $\mathrm{df}$ & $\mathrm{AIC}$ & $\Delta \mathrm{AIC}$ & $\mathrm{w}_{\mathrm{i}}$ \\
\hline MAIN & & & & & \\
1 & Year & 1 & 3847.3 & 540.0 & 0.00 \\
2 & Species & 3 & 4030.1 & 722.8 & 0.00 \\
3 & Elev class & 2 & 4163.0 & 855.7 & 0.00 \\
4 & Year + Species & 4 & 3667.3 & 360.0 & 0.00 \\
5 & Year + Elev class & 3 & 3838.6 & 531.3 & 0.00 \\
6 & Year + Species + Elev class & 6 & 3667.8 & 360.5 & 0.00 \\
INTERACTION & & & & & \\
7 & Year + Species + Year*Species & 7 & 3590.2 & 282.9 & 0.00 \\
8 & Year + Species + Elev class + 2-way & 17 & 3377.5 & 70.2 & 0.00 \\
9 & Full model & 23 & 3374.2 & 66.9 & 0.00 \\
$\mathbf{1 0}$ & Full model + year & $\mathbf{2 4}$ & $\mathbf{3 3 0 7 . 3}$ & $\mathbf{0 . 0}$ & $\mathbf{1 . 0 0}$ \\
\hline
\end{tabular}

Note: all models include the random factor of section (i.e., all plots surveyed in $5 \mathrm{~m}^{2}$ section).

Table S2. Ranking of persistence probability models for $1 \mathrm{~m}^{2}$ plots $(n=592)$. Best model identified with bold text.

\begin{tabular}{|c|c|c|c|c|c|}
\hline Model number & Model terms & df & AIC & $\triangle \mathrm{AIC}$ & $w_{i}$ \\
\hline 1 Base & Spp_yr30 Spp_yr0 & 20 & 1622.9 & 32.7 & 0.00 \\
\hline \multicolumn{6}{|l|}{ MAIN } \\
\hline 2 & Base + elevation class & 28 & 1602.1 & 11.9 & 0.00 \\
\hline 3 & Base + distance & 24 & 1602.2 & 12.0 & 0.00 \\
\hline 4 & Base + elevation class + distance & 32 & 1590.2 & 0.0 & 0.56 \\
\hline \multicolumn{6}{|l|}{ INTERACTION } \\
\hline 5 & Base ${ }^{*}$ elevation class & 52 & 1616.9 & 26.7 & 0.00 \\
\hline 6 & Base $*$ distance & 40 & 1611.6 & 21.4 & 0.00 \\
\hline 7 & Base * elevation * distance & 96 & 1643.2 & 53.0 & 0.00 \\
\hline \multicolumn{6}{|l|}{ MIXED } \\
\hline 8 & (Base $*$ elevation class) + distance & 56 & 1607.7 & 17.5 & 0.00 \\
\hline 9 & (Base $*$ distance $)+$ elevation class & 48 & 1599.0 & 8.8 & 0.01 \\
\hline 10 & Base $+($ distance $*$ elevation class $)$ & 40 & 1590.7 & 0.6 & 0.43 \\
\hline
\end{tabular}


Table S3. Ranking of persistence probability models by origin for sugar maple (ACSA). Only plots won by ACSA in 1984 included $(n=175)$. Best model identified with bold text.

$\begin{array}{llcccc}\begin{array}{c}\text { Model number } \\ 1 \quad \text { Base }\end{array} & \text { Model terms } & \mathrm{df} & \mathrm{AIC} & \Delta \mathrm{AIC} & \mathrm{w}_{\mathrm{i}} \\ \text { NO ORIGIN } & \text { Spp_yr30 Spp_yrO[ACSA only] } & 4 & 488.4 & 9.6 & 0.01 \\ 2 & & & & & \\ 3 & \text { Base + elevation class } & 12 & 491.5 & 12.7 & 0.00 \\ 4 & \text { Base + distance } & 8 & 488.1 & 9.3 & 0.01 \\ 5 & \text { Base + elevation class + distance } & 16 & 498.0 & 19.2 & 0.00 \\ \text { ORIGIN } & \text { Base * elevation * distance } & 24 & 508.5 & 29.7 & 0.00 \\ 6 & & & & & \\ 7 & \text { Base + origin } & \mathbf{1 2} & \mathbf{4 7 8 . 8} & \mathbf{0 . 0} & \mathbf{0 . 7 2} \\ 8 & \text { Base + origin + elevation class } & 20 & 484.3 & 5.5 & 0.05 \\ 9 & \text { Base + origin + distance } & 16 & 481.2 & 2.4 & 0.21 \\ & \text { Base + origin + elevation class + distance } & 24 & 491.2 & 12.4 & 0.00\end{array}$

Table S4. Ranking of persistence probability models by origin for American beech (FAGR). Only plots won by FAGR in 1984 included $(n=117)$. Best model identified with bold text.

$\begin{array}{llcccc}\begin{array}{c}\text { Model number } \\ 1 \quad \text { Base }\end{array} & \text { Model terms } & \mathrm{df} & \mathrm{AIC} & \Delta \mathrm{AIC} & \mathrm{w}_{\mathrm{i}} \\ \text { NO ORIGIN } & \text { Spp_yr30 Spp_yrO[FAGR only] } & 4 & 277.5 & 1.8 & 0.23 \\ 2 & & & & & \\ \mathbf{3} & \text { Base + elevation class } & 12 & 277.8 & 2.1 & 0.19 \\ 4 & \text { Base + distance } & \mathbf{8} & \mathbf{2 7 5 . 7} & \mathbf{0 . 0} & \mathbf{0 . 5 5} \\ 5 & \text { Base + elevation class + distance } & 16 & 282.8 & 7.1 & 0.02 \\ \text { ORIGIN } & \text { Base * elevation * distance } & 24 & 291.7 & 16.0 & 0.00 \\ 6 & & & & & \\ 7 & \text { Base + origin } & 12 & 285.1 & 9.4 & 0.00 \\ 8 & \text { Base + origin + elevation class } & 20 & 286.4 & 10.7 & 0.00 \\ 9 & \text { Base + origin + distance } & 16 & 283.5 & 7.8 & 0.01 \\ & \text { Base + origin + elevation class + distance } & 24 & 292.0 & 16.3 & 0.00\end{array}$




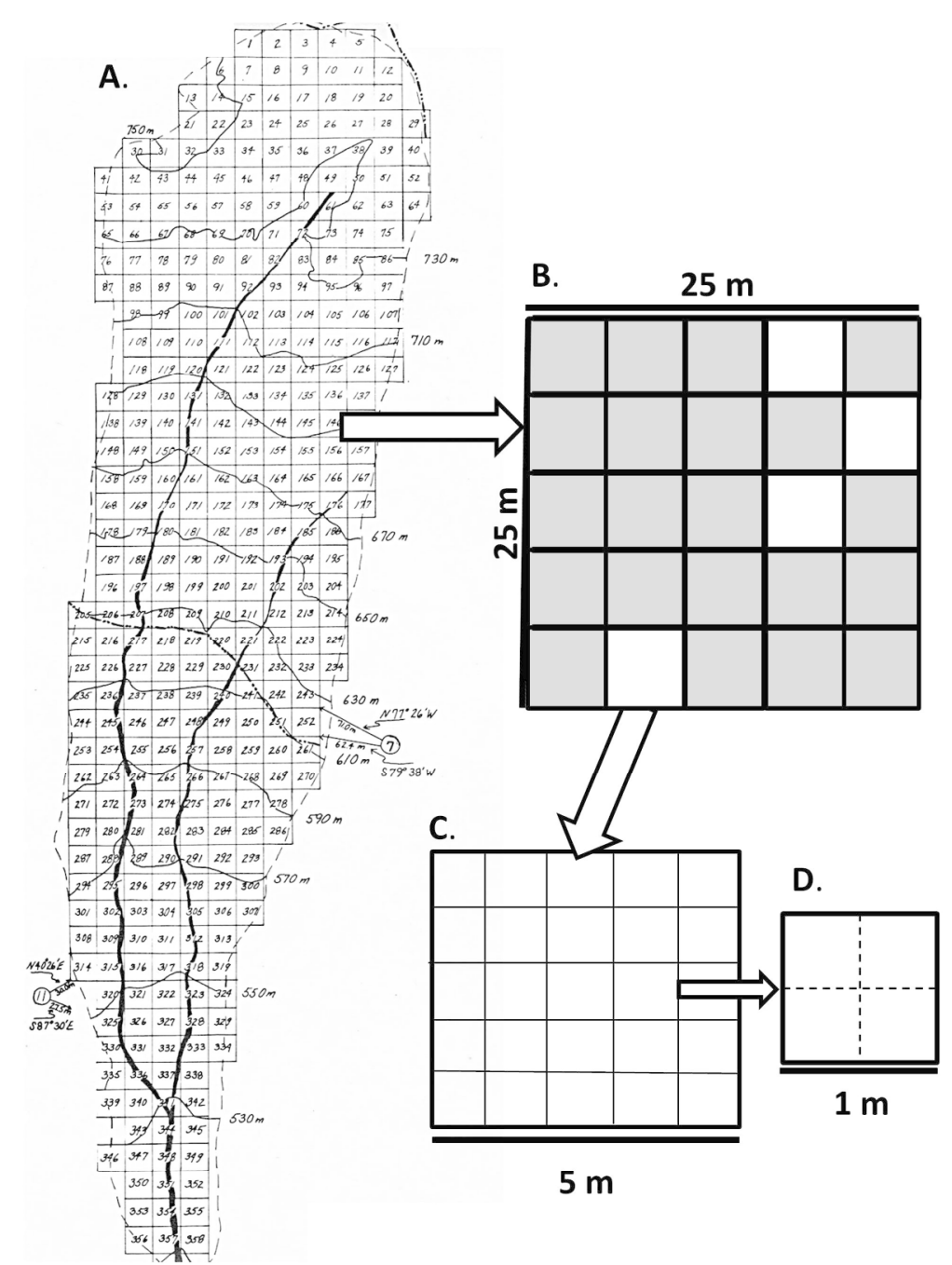

Figure S1. Permanent plot sampling scheme on Watershed 5, Hubbard brook Experimental Forest, New Hampshire, USA. A. the whole watershed gridded into $36025 \mathrm{~m}^{2}$ grid cells. B. A grid cell gridded into $255 \mathrm{~m}^{2}$ sections. C. A section gridded into $251 \mathrm{~m}^{2}$ plots. D. A plot delineated into four $0.25 \mathrm{~m}^{2}$ quadrants for data collection on each resurvey time.

$254 \times 338 \mathrm{~mm}(300 \times 300$ DPI $)$ 